\title{
PELATIHAN KESOPANAN BERBAHASA SISWA SD BERBASIS KARYA SASTRA DI PERUMAHAN CITRA BUNGO PASANG KELURAHAN SUNGAI TARUNG KECAMATAN KOTO TANGAH PADANG
}

\author{
Aruna Laila', Wahyudi Rahmat ${ }^{2}$, Samsiarni ${ }^{3}$ \\ 1,2,3 STKIP PGRI Sumatera Barat \\ Email:
}

aruna@stkip-pgri-sumbar.ac.id, wahyudirahmat24@gmail.com, samsiarni@stkip-pgri-sumbar.ac.id Submited: 2019.01.23 Reviewed: 2019.01.28 Accepted:2019.06.30

https://doi.org/10.22202/rangkiang.2019.v1.i1.37312

\begin{abstract}
Politeness in language is a soft skill that needs to be instilled in children, especially elementary schools, because the times and technological advancements require soft skills of the younger generation to develop. As a result, many children have ethics that are far from what parents and their environment want. For this problem, this reason is used as a form of coping or a way of giving attention to elementary students so that politeness in language can be maintained well. Partners in this service are PKK mothers who have children at the elementary level who live in the Citra Bungoidal housing complex. With this language courtesy training it is expected that elementary students especially those living in Citra Bungo Pasang housing will have the modesty of language in their daily lives. The language politeness of elementary school students is expected to be not only polite to parents, but also to friends, and others who are the opponents. Based on the partner's problem, the proposed solution will be implemented in two stages, namely, the first stage by providing material on language courtesy, and strategies for speaking to elementary students who live in the Citra Bungo Village housing Sungai Tarung Village, Koto Tangah District. The material is presented using power points and infocus. After the language courtesy material was given to elementary school students living in Citra Bungo Village, Sungai Tarung Subdistrict, Koto Tangah Subdistrict, students were told to interact with their friends and parents. This is done to see whether the student understands and can apply it in communication. The results of the language courtesy training given to elementary school students residing in Citra Bungo Pasang housing were observed two weeks after the material was purchased. The results were very satisfying, because elementary school students residing in the Citra Bungo Pasang housing complex which had often said rudely had changed. Because these elementary students reminded each other not to say rude.
\end{abstract}

Keywords: politeness, speaking, language

\section{ABSTRAK}

Kesopanan dalam bahasa merupakan soft skill yang perlu ditanamkan kepada anak-anak, khususnya Sekolah Dasar, karena perkembangan zaman dan kemajuan teknologi menuntut soft skill para generasi muda untuk ikut berkembang. Akibatnya banyak anak-anak yang memiliki etika yang jauh dari yang diinginkan orangtua dan lingkungannya. Untuk masalah tersebut, maka dijadikanlah alasan ini sebagai bentuk penanggulangan atau cara memberikan perhatian kepada siswa SD agar kesopanan dalam berbahasa dapat dijaga dengan baik. Mitra pada pengabdian ini adalah Ibu-ibu PKK yang memiliki anak di tingkat SD yang tinggal di perumahan Citra Bungo Pasang. Dengan adanya pelatihan kesopanan 
berbahasa ini diharapkan para siswa SD khususnya yang tinggal di perumahan Citra Bungo Pasang memiliki kesopanan berbahasa dalam kesehariannya. Kesopanan berbahasa siswa SD ini diharapkan tidak hanya sopan kepada orangtua, tetapi juga kepada teman-teman, dan orang lain yang menjadi lawan tuturnya. Berdasarkan masalah mitra, maka solusi yang ditawarkan akan dilaksanakan dalam dua tahap yaitu, tahap pertama dengan memberikan materi mengenai kesopana berbahasa, dan strategi bertutur kepada siswa SD yang bertempat tinggal di perumahan Citra Bungo Pasang Kelurahan Sungai Tarung Kecamatan Koto Tangah. Pemberian materi dipaparkan dengan menggunkan power point dan infocus. Setelah materi kesopanan berbahasa diberikan kepada siswa SD yang bertempat tinggal di perumahan Citra Bungo Pasang Kelurahan Sungai Tarung Kecamatan Koto Tangah, siswa disuruh berinteraksi dengan temannya dan orang tua. Hal ini dilakukan untuk melihat apakah siswa tersebut memahami dan dapat menerapkannya dalam berkomunikasi. Hasil dari pelatihan kesopanan berbahasa yang diberikan kepada siswa SD yang bertempat tinggal di perumahan Citra Bungo Pasang diamati dua minggu setelah materi dibeikan. Hasillnya sangat memuaskan, karena para siswa SD yang bertempat tinggal di perumahan Citra Bungo Pasang yang tadinya masih sering berkata kasar sudah mengalami perubahan. Karena siswa SD tersebut saling mengingatkan agar tidak berkata kasar.

Keywords: kesopanan, bertutur, bahasa

\section{PENDAHULUAN}

Kesopanan berbahasa adalah hal memperlihatkan kesadaran akan martabat orang lain dalam berbahasa, baik saat menggunakan bahasa lisan maupun bahasa tulis. Kesopanan berbahasa merupakan bidang kajian pragmatika dalam ilmu bahasa. Penerapan kesopanan dalam berbahasa tidak hanya ditujukan kepada orang-orang yang sudah remaja hingga dewasa, tetapi juga dituntut pada anakanak. Anak-anak adalah calon pemimpin masa depan dalam berbagai bidang. Untuk itu seorang anak memerlukan pengetahuan, bimbingan untuk mewujudkan apa yang menjadi cita-citanya. Suksesnya seseorang tidak hanya dilihat dari bidang akdemiknya, tetapi dari kesopananya. Genarasi muda pada masa sekarang ini sangat membutuhkan bimbingan untuk menyeimbangi kemajuan zaman yang berkembang pesat. Karena dampak dari kemajuan zaman sudah banyak generasi muda yang sudah kehilangan arah, bahkan tenggelam dalam kemajuan zaman. Apabila kita mengamati anak-anak yang ada di sekitar kita banyak sekali anak-anak yang tidak memiliki sopan santu dalam bertutur. Bahkan ada tuturan yang digunakanya dalam keseharian bersama teman-temannya yang tidak sepantasnya dituturkannya.

Ketidak sopanan yang terjadi di kalangan anak-anak juga terjadi akibat teknologi yang semakin cangih. Dimana semua yang diinginkan, baik yang pantas, maupun yang tidak pantas dapat dilihat, didengar, dan dibacanya lewat media tersebut. Selain itu lingkungan sekitar tempat tinggal juga berpengaruh terhadap kesopanan seorang anak dalam bertutur. Seperti kejadian yang sering terjadi di sekolah-sekolah, dimana siswa sering berkata yang tidak sopan terhadap guru yang dapat memancing emosi guru, sehingga akibatnya guru terseret ke pihak yang berwajib. Robin Lakoff (1973) menyatakan "kesopanan dikembangkan oleh masyarakat guna mengurangi friksi dalam interasi pribadi". Menurutnya, ada tiga buah kaidah yang harus dipatuhi untuk menerapkan kesopanan, yaitu formalitas (formality), ketidaktegasan (hesitancy), dan kesamaan atau kesekawanan (equality atau cameraderie).

ISSN : XXXX - XXXX

http://ejournal.stkip-pgri-sumbar.ac.id/index.php/rangkiang 
Vol. 1 (Juni 2019): $13-24$

1. Formalitas berarti jangan terdengar memaksa atau angkuh.

2. Ketidaktegasan berarti berbuatlah sedemikian rupa sehingga mitra tutur dapat menentukan pilihan.

3. Kesamaan atau kesekawanan berarti bertindaklah seolah-olah Anda dan mitra tutur menjadi sama.

Dalam bertutur kaidah-kaidah yang disampikan Robin Lakoff seharusnya diterapkan sehingga antara penutur dan lawan tutur tidak terjadi konflik. Karena lewat ketidak sopanan berbahasa konflik bisa saja terjadi antara penutur dan lawan tutur. Apabila diamati tuturan-tuturan yang terjadi antara penutur dan lawan tutur di lingkungan sekitar kaidah-kaidah yang seharusnya diterapkan pada saat berututr tidak lagi begitu diterapkan. Sehingga dapat disimpulkan yang terjadi pada masa sekarang ini kaidah-kaidah tersebut seakan-akan sudah tidak berlaku lagi dalam bertutur. Hal tejadi tidak hanya dikalangan penutur remaja saja tetapi terlihat juga dari tuturan anak-anak yang sekolah di taman kanakkanak hingga sekolah dasar, hampir disetiap tuturannya mengandung unsur memaksa dan keangkuhan. Hal ini terjadi seperti yang sudah disebutkan di atas karena menirukan tontonan yang sering mereka tonton di dunia maya. Keangkuhan dalam bertutur juga terjadi akibat kurangnya rasa sosial yang ada dalam diri anak-anak masa sekarang ini, karena mereka lebih mementingkan permainannya dibanding teman atau orang lain. Semua yang terjadi itu merupakan ketidak sopanan dalam bertutur.

Kesopanan Anak-anak SD yang tingal di perumahan Citra Bunso Pasang terjadi tidak hanya pengaruh geged yang selalu ada di tangan mereka, tetapi juga pengaruh lingkungan perumahan Citra Bungo Pasang. Dimana perumahan Citra Bungo Pasang berada di tengah-tengah penduduk asli (orang kampong). Penduduk asli yang beradasa di sekitar perumahan Citra Bungo Pasang delapan puluh persen anak-anaknya tidak sekolah. Sehingga dalam bertutur bahasa yang meraka gunakan tidak memiliki kesopanan. Bahkan hampir selalu diringi carut marut. Anak-anak pada dasarnya masih memiliki sipat meniru, sehingga apa yang didengar cendrung untuk digunakannya di waktu yang berbeda.

Berdasarkan hal tersebutlah pelatihan tentang kesopanan berbahasa ini perlu diberikan untuk siswa SD yang bertempat tinggal di perumahan Citra Bungo Pasang. Supaya lebih mudah untuk melatihnya dijadikanlah karya sastra sebagai medianya. Dijadikannya karya sastra sebagai mediannya, karena dianggap karya sastra dapat membuat anak-anak tersebut merasa mudah memahaminya dan menyenanginya lewat cerita yang ditampilkan. Dengan andanya kesopanan bertutur di kalangan anak SD yang bertempat tinggal di perumahan Citra Bungo Pasang ini diharapkan konflik tidak terjadi diantara mereka, anggota keluarga maupun guru dan teman di sekolah. Karena kesopansantunan pada umumnya berkaitan dengan hubungan antara dua partisipan yang dapat disebut sebagai 'diri sendiri' dan 'orang lain'. Misalnya tuturan anak-anak yang bertempat tinggal di perumahan Citra Bungo Pasang.

A : Kemana kak?

B : Manga tanyo-tanyo! (mengapa nanya-nanya_

A : Ikut kak.

B : Kau tadi ndak jahek tu yo. (kamu tadi jahat)

A : Ikut kak...

C : e...pajatu ndak pandai main tu (anak itu tidak pandai bermain) 
B :Anak ketek jo anak ketek, kamu jalan di belakang yo. Awas kalau mada.

(anak kecil sama anak kecil, kamu jalan di belakang ya, awas nakal)

Tuturan di atas terjadi antara anak yang usianya lebih kecil dari lawan tuturnya. Dari penggalan tuturan tersebut terlihat ketidak sopanan antara yang lebih tua dengan yang lebih besar. Seharusnya penutur yang usianya lebih besar akan memiliki kesantunan yang lebih baik. Karena penutur tidak memulai tuturannya dengan ketidaksopanan, tetapi malah dibalas dengan ketidaksopanan. Letak ketidak sopanannya terlihat dari tuturan "manga tanyo-tanyo". "e...pajatu ndak pandai main tu". Kalau penutur membalas tuturan lawan tutur sesuai dengan tutura lawan tutur konflik akan terjadi diantara mereka, karena merasa tituran di atas tidak senang dengan jawaban yang ibererikan. Dari tuturan lawan tutur tidak satu pun tuturannya yang mengandung kesopanan. Apabila hal ini terjadi berlarut-larut dalam peruturan saat mereka berinteraksi maka akan berdampak negatif kepada lawan tutur dan partisipan lainnya.

Kesantunan terletak bukan pada bentuk dan kata-kata, melainkan pada fungsi dan makna sosial yang diacu. Jika penutur mengatakan bentuk yang lebih sopan daripada konteks yang diperlukan, mitra tutur akan menduga bahwa ada maksud khusus yang tersembunyi. Berdasarkan hal tersebutlah pengabdian tentang "Pelatihan Kesopanan Berbahasa Siswa SD Berbasis Karya Sastra di Perumahan Citra Bungo Pasang Kelurahan Sungai Tarung" ini perlu dilakukan.

Seiring dengan perkembang zaman yang semakin maju, teknologi yang semakin cangggih, masyarakat yang semakin modern berdampak pada kesopanan berbahasa. Jika dibandingkan anak atau orang-orang yang hidup pada tahun 70an dengan tahun 80an kesopanan berbahasanya sangat jauh berbeda. Pada masa 20an ini kesopanan anak-anak, remaja sepertinya sudah jauh berkurang. Hal ini mungkin terjadi karena kurangnya rasa sosial masyarakatnya sehingga tuturannya kurang sopan. Hal ini terjadi pada berbagai kalangan masyarakat. Tidak tertutup kemungkinan terjadi pada anak-anak yang belum remaja atau anak-anak yang masih duduk di banku Sekolah Dasar (SD). Kesopan merupakan hal yang sangat wajib dilakukan pada saat bertutur dengan siapa pun. Karena bahasa merupakan alat yang sangat penting bagi manusia. Tanpa bahasa manusia akan kesulitan berintekrasi dengan dengan sesamanya, karena bahasa berfungsi sebagai alat komunikasi dalam berinteraksi sosial. Achmad (2013: 3) mengatakan bahwa bahasa adalah sistem lambang bunyi yang arbitrer yang dipergunakan oleh para anggota sosial untuk bekerja sama, berkomunikasi, dan mengidentifikasi diri. Bahasa yang digunakan untuk bekerjasama dan berkomunikasi seharusnya memilliki prinsip kerja sama dan prinsip kesopanan. Hal ini dilakukan untuk menjaga kelangsungan komunikasi.

Kesopanan dalam berbahasa merujuk pada tatakrama, etika dalam berkomunikasi atau berinteraksi dengan orang lain. Dalam kesopanan berbahasa dituntut penggunaan bahasa yang halus, ramah, santun, dan tidak menyinggung perasaan lawan tutur. Ketika berinteraksi setiap penutur selayaknya dituntut memilki kesopanan demi menjaga lancarnya komunikkasi yang dijalin, apabila salah seorang penutur atau lawan tutur tidak memilki kesopanan berbahasa maka akan mengakibatkan terganggungnya peristiwa tutur karena akan menimbulkan ketersinggungan. Ketidak sopanan berbahasa dilihat dari bahasa yang dituturkan berupa tuturan yang marah-marah, tidak sopan, dan yang menyinggung perasaan. Masalah ini sesuai dengan hasil penelitian yang telah dilakukan Ismet, M. N. (2014). Berdasarkan penelitian yang dilakukan Ismet ditemukan bahwa penggunaan tuturan dengan 
Vol. 1 (Juni 2019): $13-24$

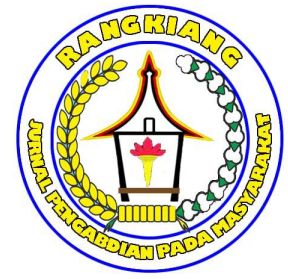

menggunakan prinsip kesopanan dalam sebuah percakapan sangat penting. Hal ini dilakukan penutur dan lawan tutur untuk menciptakan sebuah suasana yang nyaman dalam percakapan sehingga baik dari penutur maupun petutur tidak ada yang merasa tersinggung atau terjadi sebuah kesalah pahaman dalam komukasi.

Kesopanan bahasa dapat juga diwujudkan dengan penyimpangan bahasa agar bahasa yang dituturkan memiliki kesopanan dan lawan tutur dapat merasakan kebahagiaan mendengar tuturan tersebut. Berdasarkan penelitian yang dilakukan terhadap penyimpangan bahasa dan kesopanan diketahui bahwa penggunaan penyimpangan bahasa tersebut tidak selalu bernilai negatif karena penyimpangan tersebut ada yang bernilai tentang agama khususnya dalam kehidupan dan penggunaan penyimpangan bahasa tersebut disengaja oleh penulis dengan bertujuan untuk memunculkan kelucuan dan membuat pembaca ketawa (Darmawan, Y. A. (2015).

Kesopanan berbahasa merupakan cerminan dari pengguna bahasa tersebut. Prinsip kesopanan yang digunakan penutur dan lawan tutur berhubungan erat dengan latar sosial, dan budaya penuturnya serta konteks tuturannya. Berdasarkan penelitian yang dilakukan Beden terhadap pemetaan struktur peristiwa bahasa komunikasi bebas kinflik, komunikasi bebas konflik dapat memberikan kebaikan kepada generasi muda dalam bertutur tentang cara yang baik untuk berkomunikasi. Hal itu dilakukan dengan memahami atau menganalaisis siapa lawan tutur, atau penutur serta tujuan dan konteks tuturan tersebut berlangsung. Dengan diketahuinya siapa lawan tutur, penutur, serta tujuan dan konteks tuturan kesopanan generasi muda akan sesuai dengan aspirasi dalam Falsafah Pendidikan Kebangsaan untuk melahirkan insan yang seimbang dan harmonis (Beden, $\mathrm{S}$. B., dan Zahid, I. B. 2016). Syariah, S., Martono, M., \& Sanulita, H. juga melakukan penelitian tentang kesantunan, menurut syariah selama berkomunikasi baik dari kalangan sosial menengah ke atas hingga menengah ke bawah dan dari yang muda hingga yang tua, merepresentasikan maksim-maksim yang terdapat dalam prinsip kesantunan.

\section{METODE}

Pelatihan ini menggunakan waktu 60 menit dengan perincian, 20 menit teori, 10 menit tanyajawab, 10 menit diskusi, dan 20 menit pengamatan penggunaan bahasa siswa, Pelaksanaan tahap I dilakukan oleh seluruh pelaksana kegiatan dan materi disajikan oleh wahyudi Rahmat, M.Hum. Tahap selanjutnya, pengamatan kesopanan berbahasa.

Berdasarkan masalah di atas, permasalahan mitra adalah sebagai berikut:

1. Faktor lingkungan tempat tinggal. Lingkungan adalah tempat seseorang saling berinteraksi dengan sesame, yaitu orang yang ada di sekitarnya baik yang sudah lama metetap di lingkungan tersebut, maupun yang baru menetap. Lingkungan juga merupkan tempat seseorang mengidentifikasi diri, mengembangkan diri, dan memperlihatkan jati diri. Jika di lingkungan tempat tinggal penduduknya memperlihatkan perilaku yang baik, sopan, ramah, beretika, maka tidak tertututp kemungkinan orang-orang yang ada disekitarnya juga ikut baik secara keseluruhan. Tetapi apabila yang terjadi malah sebaliknya, maka orang-orang yang ada disekitarnya juga kan tidak baik. Begitulah yang terjadi di perumahan Citra Bungo Pasang Kelurahan Sungai Tarung Kecamatan Koto Tangah. Perumahan Citra Bungo Pasang dihuni oleh pemiliknya sejak tahun 2014. Pemilik rumah yang ada di perumahan ini seratus persen adalah pendatang, dengan pekerjaaan yang beragam. Perumahan Citra Bungo Pasang ini dikelilingi oleh 
Vol. 1 (Juni 2019): $13-24$

masyarakat penduduk asli kelurahan Sungai Tarung yang pada umumnya orangtuanya tidak meiliki pendidikan, begitu juga dengan anak-anaknya. Sehingga dalam betutur penduduk asli Kelurahan Sungai Tarung tidak memiliki sopan santun. Mereka bertutur dengan suara yang sangat keras, baik anak-anaknya maupun orang tuanya. Anak-anak penduduk asli kelurahan Sungai Tarung selalu mendekatkan diri dengan anak-anak perumahan, sehingga dalam berinteraksi mereka juga tidak membedakan meraka bertutur dengan siapa. Karena itu, anakanak perumahan sering mendengar tuturan-tuturan yang tidak sopan dari lingkungan.

2. Faktor perbedaan umur dan jenis kelamin. Kesopanan berbasa antara penutur dan mita tutur dipengaruhi oleh umur dan jenis kelamin. Hal ini terjadi karena penutur atau lawan tutur yang usianya lebih tua menganggap lawan tuturnya bisa saja menggunakan bahasa yang tidak sopan, hail ini diakibatkan adanya anggapan bahwa penutur atau lawan tutur yang usianya paling besasr akan berkuasa terhadap yang paling kecil. Anggapan ini terjadi karena usia yang lebih tua lebih banyak taunya dari pada yang kecil. Padahal kalau dilihat dari ilmu pragmatik hal ini tidak boleh terjadi. Dalam bertutur diperlukan maksim kesopanan yang harus ditaati.

3. Faktor teknologi. Dengan berkembangnya teknologi yang semakin canggih berdampak negatif terhadap kesopanan berbahasa seorang anak. Seorang anak yang hidup dalam keluarga sederhana, menengah, dan atas dapat menggunakan gejed dengan sesukanya. Lewat gejed anak dapat menonton dan membaca berbagai hal. Sebagai mana diketahui bahwa gejed lebih berdampak positif daripada dampak negatif. Lewat apa yang ditontong oleh seorang anak dari dalam gejed secara tidak langsung seorang anak sudah belajar bahasa yang didengarnya. Karena belum bisa menyaring mana yang baik dan buruk secara kritik, maka anak tersebut menggunakan bahasa yang didengarnya di dalam bergaul dengan teman-temannya padahal bahasa yang digunakan bukanlah bahasa yang sopan.

4. Faktor sosial budaya yang meliputi keluarga, dan ekonomi. Seorang anak yang dilahirkan dari keluarga yang memiliki pendidikan yang baik, akan menuntut anaknya menggunakan bahasa yang baik dan sopan. Namun anak yang lahir dari keluarga yang pendidikannya kurang atau tidak berpendidikan tidak meimikirkan tentang penggunaan bahasa anaknya. Sementara anak yang lahir dari keluarga berpendidikan dan tidak berpendidikan bergaul di lingkungan sosialnya. Sehingga seorang anak yang tadinya diajarkan untuk memiliki keksopanan dalam berbahasa baik dengan sesama teman, kakak-kaka, atau yang sudah berusia tua akhirnya terpengaruh dengan bahasa yang tidak sopan yang didengarnya dari temannya.

Berikut ini solosi yang ditawarkan untuk mengatasi permasalahan yang berhubungan dengan kesopanan berbahasa serta target luaran yang diharapkan dari pengabdian ini.

Untuk memecahkan masalah mitra, para siswa SD yang bertempat tinggal di Perumahan Citra Bungo Pasang Kelurahan Sungai Tarung Kecamatan Koto Tangah memerlukan pengetahuan dan bimbingan yang lebih intensif mengenai kesopanan dalam bertutur baik dengan teman sebaya, lebih kecil, maupun dengan orang yang lebih tua. Tujuan yang hendak dicapai melalui kegiatan pengabdian kepada masyarakat adalah untuk mengetahui hal berikut.

a. Mengetahui apakah para siswa SD yang bertempat tinggal di Perumahan Citra Bungo Pasang Kelurahan Sungai Tarung Kecamatan Koto Tangah menuturkan bahasa yang memiliki kesopanan. 
Vol. 1 (Juni 2019): $13-24$

b. Memberikan pendidikan (pengetahuan) kepada siswa SD yang bertempat tinggal di Perumahan Citra Bungo Pasang Kelurahan Sungai Tarung Kecamatan Koto Tangah teori prinsip kesopanan dalam berbahasa.

c. Untuk memperoleh umpan balik dan masukan bagi Program Studi Pendidikan Bahasa dan Sastra Indonesia dalam rangka meningkatkan relevansi pendidikan.

Berdasarkan masalah mitra, maka solusi yang ditawarkan akan dilaksanakan dalam dua tahap yaitu, tahap pertama dengan memberikan materi mengenai kesopana berbahasa, dan strategi bertutur kepada siswa SD yang bertempat tinggal di perumahan Citra Bungo Pasang Kelurahan Sungai Tarung Kecamatan Koto Tangah. Pemberian materi dipaparkan dengan menggunkan power point dan infocus.

Setelah materi kesopanan berbahasa diberikan kepada siswa SD yang bertempat tinggal di perumahan Citra Bungo Pasang Kelurahan Sungai Tarung Kecamatan Koto Tangah, siswa disuruh berinteraksi dengan temannya dan orang tua. Hal ini dilakukan untuk melihat apakah siswa tersebut memahami dan dapat menerapkannya dalam berkomunikasi.

\section{HASIL DAN PEMBAHASAN}

\section{A. Pengertian Pragmatik}

Menurut Leech (1993:8), pragmatik adalah studi tentang makna dalam hubungannya dengan situasi-situasi ujar (speech situations) yang meliputi unsur-unsur penyapa dan yang disapa, konteks, tujuan, tindak ilokusi, tuturan, waktu, dan tempat. Menurut Searle (dalam Leech, 1993:32) tindak ujar, juga tindak ilokusi, ditentukan oleh kaidah-kaidah. Bagi Searle, sebuah ilokusi dapat dianggap sebagai suatu janji, perintah, permohonan, dan sebagainya yang diatur oleh seperangkat kaidah tertentu yang masing-masing diklalsifikasikan sebagai kaidah isi proposisional (propositional content rules), kaidah persiapan (preparatory rules), kaidah ketulusan (sincerity rules) dan kaidah esensial (essential rules) (Leech, 1993:32). Fungsi ilokusi sesuai dengan hubungan fungsi-fungsi tersebut dengan tujuan-tujuan sosial berupa pemeliharaan perilaku yang sopan dan terhormat berupa kompetitif, menyenangkan, bekerja sama, dan bertentangan. Sementara menurut Gunarwan (1994:39), istilah pragmatik lahir dari seseorang filsuf yang bernama Charles Morris.

Dari beberapa pengertian di atas, dapat disimpulkan bahwa pragmatik merupakan cabang ilmu bahasa yang mengkaji segala aspek makna tuturan berdasarkan maksud penutur dan hubungannya dengan situasi tutur. Pragmatik juga mengkaji makna tuturan berdasarkan konteksnya.

\section{B. Aspek-aspek Pragmatik}

Berikut ini adalah kriteria acuan pada aspek situasi ujar yang dikemukakan oleh Leech (1993: 1920):

(1) Yang menyapa (penyapa) atau yang disapa (pesapa)

Orang yang menyapa merupakan penutur dan orang yang disapa adalah petutur. Penggunaan penutur dan petutur tidak membatasi pragmatik pada bahasa lisan saja.

ISSN : XXXX - XXXX

http://ejournal.stkip-pgri-sumbar.ac.id/index.php/rangkiang 
Vol. 1 (Juni 2019): $13-24$

(2) Konteks sebuah tuturan

Konteks merupakan aspek yang berhubungan dengan lingkungan fisik atau tempat dan sosial sebuah tuturan

(3) Tujuan sebuah tuturan

Tujuan sebuah tuturan dapat digunakan secara umum untuk kegiatan-kegiatan yang berorientasi tujuan.

(4) Tuturan sebagai bentuk tindakan atau kegiatan: tindak ujar

Pragmatik berurusan dengan tindak-tindak/performansi-performansi verbal yang terjadi dalam situasi dan waktu tertentu.

(5) Tuturan sebagai produk tindak verbal

Selain sebagai tindak ujar atau tindak verbal, dalam pragmatik tindak tindak tutur dapat digunakan sebagai produk suatu tindak verbal.

\section{Hakikat Tindak Tutur}

Teori yang akan dibahas dalam sub hakikat tindak tutur ini adalah: pengertian tindak tutur, jenisjenis tindak tutur, tindak tutur ekspresif, dan strategi bertutur dalam tindak tutur ekspresif.

\section{Pengertian Tindak Tutur}

Tindak tutur merupakan gejala individu, bersifat psikologis, dan ditentukan oleh kemampuan bahasa penutur dalam menghadapi situasi tertentu. Tindak tutur di titikberatkan kepada makna atau arti tindak, sedangkan peristiwa tutur lebih dititikberatkan pada tujuan peristiwanya (Suwito, 1993:33). Sedangkan menurut Chaer dan Agustin (2010:50) menjelaskan tindak tutur merupakan gejala individual bersifat psikologis dan keberlangsungan ditentukan oleh kemampuan bahasa si penutur dalam menghadapi situasi tertentu. Tindak tutur merupakan suatu bentuk tindakan dalam konteks situasi tutur. Hal ini sejalan dengan pendapat Yule (2006: 82) yang menyatakan bahwa tindak tutur adalah tindakantindakan yang ditampilkan lewat tuturan, dan dalam bahasa Inggris secara umum diberilabel yang lebih khusus, misalnya, permintaan maaf, keluhan, pujian, undangan, janji atau permohonan. Richard (dalam Syahrul, 2008:31) mengatakan bahwa kegiatan bertutur dianggap sebagai tindakan, berarti dalam setiap kegiatan bertutur terjadi tindak tutur. Chaer (1995:65) juga mengatakan bahwa tindak tutur lebih dilihat pada makna atau arti tindakan dalam tuturannya.

Berdasarkan pendapat beberapa ahli di atas dapat disimpulkan bahwa tindak tutur merupakan makna atau arti dari tuturan. Makna dari tuturan tersebut tergantung konteks situasi tutur. Berdasarkan konteksnya tindak tutur itu ada yang berupa permintaan maaf, memuji, mengucapkan selamat, menyalahkan mengucapkan belasungkawa dan lain sebagainya.

\section{Hakikat Bahasa}


Vol. 1 (Juni 2019): $13-24$

Dalam kajian lungiustik umum bahasa, baik sebagai langage maupun langue, lazim didefinisikan sebagai sebuah lambang bunyi yang bersifat arbitrer yang digunakan manusia sebagai alat komunikasi atau alat interaksi sosial. Sebagi sebuah system, bahasa mempunyai struktur dan kaidah tertentu yang harus ditaati oleh para penuturnya (Chaer, 2010:14). Untuk itu para penutur bahasa dituntut untuk memiliki kesantunan dalam menyampaikan bahasa.

Kesantunan berbahasa lebih berkenaan dengan substansi bahasanya, maka etika berbahasa lebih berkenaan tingkahlaku di dalam bertututr. Dalam hal ini Masinambouw (dalam Chaer, 2010:6) mengatak bahwa sistem bahasa mempunyai fungsi sebagai sarana berlangsungnya suatu interaksi manusia di dalam masyarakat. Ini berarti didalam tindak laku berbahasa haruslah disertai norma yang berlaku di dalam budaya itu. Menurut Geerts (dalam Chaer, 2010:6) system tindk laku berbahasa menurut norma-norma budaya itu disebut eika berbahasa atau tata cara berbahasa.

Menurut Chaer $(2010,6)$ etika berbahasa ini erat kaitannya dengan norma-norma sosial dan system budaya yang berlaku dalam suatu masyarakat. Maka etika berbahas itu akan mengatur seseorang dalam hal (a) apa yang harus dikatakan kepada seseoranglawan tutur pada waktu dan keadaan tertentu berkenaan dengan status sosial budaya dalam masyarakat itu. (b) ragam bahasa paling wajar digunakan dalama waktu dan budaya tertentu. (c) kapan dan bagaimana kita menggunakan giliran berbicara, menyela, interupsi pembicaraan orang lain. (d) kapan kita harus diam mendengar tuturan orang lain. (e) bagaima kulitas suara keras, pelan, meninggi dan bagaimana sikap fisik kita didalam berbicara.

\section{E. Konsep Dasar Kesantunan Berbahasa}

Beberpa pakar ada yang membahas kesantunan berbahasa yaitu Lakoff, Fraser, Brown dan Levinson, dan Leech. Secara singkat dan umum para ahli tersebut ada tiga kaidah yang harus dipatuhi agar tuturan terdengar santun oleh lawan tutur atau pendengar. Ketiga kaida tersebut adalah (1) formalitas, (2) ketidak tegasan, (3) kesamaan dan kesewenangan.

Bila dijabarkan kaidah yang pertama berarti jangan memaksa atau jangan angkuh, kaidah yang kedua berarti buatlah sedemikian rupa agar sehingga lawan tutur atau lawan bicara dapat menentukan pilihan, dan kaidah yang ketiga berarti bertindaklah seolah-olah Anda dan lawan tutur menjadi sama (Chaer, 2010:10-11).

Menurut Lakoff (1973) kalau tuturan kita ingin terdenga santun di telinga pendengar atau lawan tutur, ada tiga kaidah yang kesantunan yang harus menurut Lakoff yaitu formalitas, ketidaktegasan, dan pesamaan dan kesekawanan. Jadi menurut Lakoff, sebuah tutuan dikatakan santun apabila tidak terdengar memksa atau angkuh, tuturan itu member pilihan kepda lawan tutur, dan lawan tutur merasa tenang. Menurut Fraser (1978) dan Gunarwan (1994) membahas kesantunan berbahasa bukan atas dasar kaidah-kaidah, melainkan atas dasar strategi. Fraser juga membedakan kesantunan (politeness) dari penghormatan (deference). Bagi Fraser (1978) kesantunan adalah property yang diasosiasikan dengan tuturan dan didalam hal ini menurut pendapat si lawan tutur, bahwa si penutur tidak melampaui hak-haknya atau tidak mengingkari dalam memenuhi kewajibannya. Sedangkan penghormatan adalah bagian dari aktivitas yang berfungsi sebagai sarana simbolis untuk menyatakan penghargaan secara regular.

Mengenai kesantunan dari Fraser, menurut Gunawan (1994) ada tiga hal yang yang perlu diulas. Pertama kesantunan itu adalah properti atau bagian dari tuturan, jadi bukan tuturan itu sendiri. kedau, pendapat pendengarlah yang menentukan apakah kesantunan itu terdapat pada sebuah tuturan. Mungkin saja sebuah tuturan dimaksudkan sebagi tuturan yang santun oleh si penutur, tetapi di telinga 
Vol. 1 (Juni 2019): $13-24$

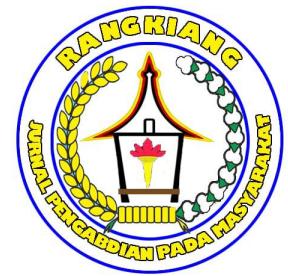

lawan tutur, tuturan itu ternyata tidak terdengar santun, begitu pula sebaliknya.ketiga, kesantunan itu dikaitkan dengan hak dan kewajiban peserta pertuturan. Artinya apakah sebuah tuturan terdengar santun atau tidak diukur berdasarkan (a) apakah si penutur tidak melampaui haknya terhadap lawan tuturnya, dan (b) apakah si penutur memenuhi kewajibanya kepada lawan tuturnya itu.

Menurut Brouwn dan Levinson (1978) teori tentang kesantunan berbahasa itu berkisar antara muka, yakni citra diri. Muka itu meliputi dua aspek yang saling berkaitan yaitu muka negatif dan muka positif. Muka negatif mengacu pada citra diri seseorang yang rasional yang berkeinginan agar ia dihargai dengan jalan membiarkannya bebas melakukan tindakan atau membiarkannya bebas dari keharusan mengerjakan sesuatu. Bila tindak tuturnya bersifat direktif misalnya perintah atau permintaan yang terancm adalah muka negatif. Hal ini karena memerintah atau meminta seseorang melakukan sesuatu, kita sebenarnya sudah menghalangi kebebasannya untuk melakukan. Sedangkan yang dimaksud dengan muka positif adalah sebaliknya, yakni mengacu pada citra diri setiap orang yang rasional, yang berkeinginan untuk melakukannya, apa yang dimilikinya atau apa yang merukapan nilai-nilai yang diyakininya sebagai akibat apa yang dilakukannya.

Karena ada dua sisi muka, maka kesantunan pun dibagi menjadi dua, yaitu kesantunan negatif untuk menjaga menjaga muka negatif, dan kesantunan positif untuk menjaga muka positif. Sopan santun dalam pertuturan direktif termasuk termasuk ke dalam kesantunan negative yang dapat diartikan sebagi usaha untuk menghindarkan konflik penutur-lawan tutur.

\section{F. Kesopanan}

Dalam setiap pertuturan setidaknya memiliki empat kompenen berikut ini: (1) partisipan yang terdiri dari penutur dan lawan tutur; (2) pesan, yaitu isi dari tuturan yang disampaikan; (3) konteks situasi yaitu keadaan dan suasana tempat tuturan terjadi; (4) bahasa atau ragam bahasa yang digunakan.

Sebuah tuturan dianggap benar apabila tuturan itu mematuhi empat maksim kerjasama yaitu maksim kualitas, maksim kunatitas, maksim relevansi, maksim cara. Lalu tuturan dianggap santun apabila mematuhi keenam maksim kesopanan yaitu kebijaksanaan, penerimaan, kemurahan, kerendahan hati, kesetujuan, dan kesimpatian. Apakah suatu tuturan yang sudah benar dan santun, juga berarti memenuhi syarat kesopanan? Belum tentu. Karena kalau tuturan yang benar berkaitan dengan masalah isi tuturan, kalau tuturan yang santun berkaitan dengan bahasa yang digunakan, yaitu bahasa dengan ciri-ciri kesantunan, maka tuturan yang sopan berkaitan dengan topic tuturan, konteks situasi penuturan, dan jarak hubungan sosial antara penutur dan lawan tutur.

\section{G. Strategi Bertutur}

Menurut Brown dan Levinson, strategi bertutur ada lima, yaitu:

(1) Bertutur terus terang tanpa basa-basi

(2) Bertutur terus terang dengan basa-basi kesantunan positif

Strategi bertutur dengan basa basi kesantunan positif ini memiliki sepuluh strategi yaitu (a) tuturan menggunakan penanda identitas sebagai kelompok yang sama, (b) tuturan memberikan alasan, (c) tuturan melibatkan penutur dan mitra tutur dalam suatu kegiatan, (d) tuturan mencari kesepakatan, (e) tuturan melipatgandakan simpati kepada mitra tutur, (F) tuturan berjanji, (g) tuturan 
Vol. 1 (Juni 2019): $13-24$

memberikan penghargaan kepada mitra tutur, (h) tuturan bersifat optimis kepada mitra tutur, (i) tuturan bergurau, (j) tuturan menyatakan saling membantu.

(3) Bertutur dengan basa-basi kesantunan negatif

Startegi bertutur ini dalam bentuk strategi berikut ini, (a) tuturan berpagar, (b) tuturan tidak langsung, (c) tuturan meminta maaf, (d) tuturan meminimalkan beban, (e) tuturan impersonal, (f) tuturan permintaan dalam bentuk pertanyaan, (g) tuturan yang menyatakan kepesimisan, (h) tuturan yang mengungkapkan pernyataan sebagai aturan umum, 9i) tuturan yang menyatakan rasa hormat.

(4) Bertutur samar-samar

Strategi bertutur samar-samar ini dikelompokkan menjajdi dua yaitu, (a) tuturan yang mengandung isyarat kuat, yang mengacu pada tuturan yang mempunyai daya ilokusi kuat, (b) tuturan yang mengandung isyarat lunak yang mengacu pada tuturan yang mempunyai daya ilokusi lunak.

(5) Bertutur dalam hati.

\section{SIMPULAN}

Pragmatik adalah studi tentang makna dalam hubungannya dengan situasi-situasi ujar (speech situations) yang meliputi unsur-unsur penyapa dan yang disapa, konteks, tujuan, tindak ilokusi, tuturan, waktu, dan tempat. Jadi pragmatik merupakan cabang ilmu bahasa yang mengkaji segala aspek makna tuturan berdasarkan maksud penutur dan hubungannya dengan situasi tutur. Pragmatik juga mengkaji makna tuturan berdasarkan konteksnya. Tindak tutur merupakan gejala individu, bersifat psikologis, dan ditentukan oleh kemampuan bahasa penutur dalam menghadapi situasi tertentu. Tindak tutur di titikberatkan kepada makna atau arti tindak, sedangkan peristiwa tutur lebih dititikberatkan pada tujuan peristiwanya.

Kesantunan berbahasa lebih berkenaan dengan substansi bahasanya, maka etika berbahasa lebih berkenaan tingkahlaku di dalam bertutur. Dalam setiap pertuturan setidaknya memiliki empat kompenen berikut ini: (1) partisipan yang terdiri dari penutur dan lawan tutur; (2) pesan, yaitu isi dari tuturan yang disampaikan; (3) konteks situasi yaitu keadaan dan suasana tempat tuturan terjadi; (4) bahasa atau ragam bahasa yang digunakan.

Sebuah tuturan dianggap benar apabila tuturan itu mematuhi empat maksim kerjasama yaitu maksim kualitas, maksim kunatitas, maksim relevansi, maksim cara. Lalu tuturan dianggap santun apabila mematuhi keenam maksim kesopanan yaitu kebijaksanaan, penerimaan, kemurahan, kerendahan hati, kesetujuan, dan kesimpatian. Apakah suatu tuturan yang sudah benar dan santun, juga berarti memenuhi syarat kesopanan? Belum tentu. Karena kalau tuturan yang benar berkaitan dengan masalah isi tuturan, kalau tuturan yang santun berkaitan dengan bahasa yang digunakan, yaitu bahasa dengan ciri-ciri kesantunan, maka tuturan yang sopan berkaitan dengan topik tuturan, konteks situasi penuturan, dan jarak hubungan sosial antara penutur dan lawan tutur.

\section{DAFTAR PUSTAKA}

Achmad dan Abdullah Alek. (2013). Linguistik Umum. Jakarta: Erlangga.

Beden, S. B., \& Zahid, I. B. (2016). Pemetaan struktur peristiwa bahasa: Komunikasi bebas konflik. GEMA Online ${ }^{\circledR}$ Journal of Language Studies, 16 (1).

ISSN : XXXX - XXXX

http://ejournal.stkip-pgri-sumbar.ac.id/index.php/rangkiang 
Brown, Penelope, Stehen Levinson. 1978. Universal in Language Usage: Politeness Phenomena. Combridge University Press.

Darmawan, Y. A. (2015). Penyimpangan Prinsip Kerja Sama dan Prinsip Kesopanan pada Novel Humor Bukan 3 Idiot Karya Boim Lebon (Doctoral dissertation, Universitas Muhammadiyah Surakarta).

Ismet, M. N. (2014). "Aspek Sopan Santun Ujaran Dalam Film Eat Pray Love Karya Ryan Murphy (Analisis Pragmatik)". Jurnal Elektronik Fakultas Sastra Universitas Sam Ratulangi, 2 (1).

Leech, G.G. 1983. Principles of Pragmatics. New York: Logman.

Syariah, S., Martono, M., \& Sanulita, H. "Prinsip Kesantunan dalam Novel Rindu Karya Tere Liye". Jurnal Pendidikan dan Pembelajaran, 7(7). 